\title{
Dymitr Grygiencza
}

badacz niezależny

\section{Bitwa pod Sarbinowem (1758) w świetle listów oficerów rosyjskich: nowa publikacja o rosyjskiej armii doby wojny siedmioletniej}

[Rec. Denis Anatol’evič Sdvižkov, Pis'ma s Prusskoj vojny. L di Rossijsko-imperatorskoj armii v 1758 godu, Moskva 2019]

\begin{abstract}
Abstrakt: Przedmiotem recenzji jest książka Denisa Sdvižkova poświęcona rosyjskiej armii w bitwie pod Sarbinowem (1758) w czasie wojny siedmioletniej. Analizując prywatne listy rosyjskich oficerów w antropologicznej perspektywie i umieszczając je w szerokim kontekście kulturowym, autor proponuje nowe spojrzenie na tę słynną batalię — oddając głos stronie, która dotychczas pozostawała milcząca.

Słowa kluczowe: wojna siedmioletnia, bitwa pod Sarbinowem, Zorndorf, armia rosyjska, historia militarna

Mniej więcej w miesiąc po bitwie pod Sarbinowem, która rozegrała się 25 sierpnia 1758 roku w okolicach Kostrzyna (niem. Küstrin) między wojskami Fryderyka II a rosyjską armią, pruskiemu oddziałowi udało się przechwycić w przygranicznym miasteczku rosyjskiego kuriera. $\mathrm{W}$ jego torbie znajdowało się około stu listów, z których większość napisana była po rosyjsku, ale także po niemiecku, francusku i nawet po gruzińsku. Tylko niewielką część stanowiły oficjalne depesze wojskowego dowództwa do Petersburga; zdecydowanie więcej było krótkich prywatnych listów rosyjskich oficerów do ich rodzin i przyjaciół, zawierających świeże jeszcze wrażenia po niedawnej bitwie. Niektóre dokumenty świadczące o ciężkim stanie rosyjskiej armii zostały później wykorzystane przez pruską propagandę, która usiłowała udowodnić zwycięstwo Fryderyka II. Dla reszty papierów urzędnicy nie
\end{abstract}


znaleźli żadnego zastosowania, dzięki temu cała masa listów trafiła do zbiorów archiwum pruskiej Tajnej Rady (obecnie Tajne Archiwum Państwowe Fundacji Pruskiego Dziedzictwa Kulturalnego - Geheimes Staatsarchiv Preußischer Kulturbesitz). Znaleziony i opracowany przez rosyjskiego historyka Denisa Sdvižkova notabene znanego polskiemu czytelnikowi dzięki opublikowanej po polsku monografii Epoka inteligencji. Historia poo wnawcza warstwy wykszta iconej w Europie ${ }^{1}$ cały ten kompleks świadectw osobistych został w 2019 roku wydany w jego książce, która stanowi przedmiot niniejszej recenzji².

Nierozstrzygnięta batalia pod Sarbinowem (niem. Zorndorf), jedna z największych i najbardziej krwawych bitew wojny siedmioletniej, zostawiła znaczny ślad w historiografii i pamięci historycznej, szczególnie w pruskiej — w Rosji bowiem wojna siedmioletnia nigdy nie cieszyła się takim zainteresowaniem. Fakt, że pole bitwy — wówczas w pruskiej Nowej Marchii — znalazło się w dzisiejszych granicach Polski i staje się atrakcją militarno-turystyczną ${ }^{3}$, sprzyja rosnącemu zainteresowaniu bitwą również wśród polskich historyków. Poświęcone jej publikacje ukazują się z dużą regularnością ${ }^{4}$. Pole bitwy jest obiektem badań archeologicznych ${ }^{5}$, a w 2011 roku pojawiła się pierwsza zbiorowa praca polskich autorów dotycząca bitwy ${ }^{6}$. Nowa książka D. Sdvižkova jest niewątpliwie istotnym dopełnieniem wiedzy o kampanii

1 D. Sdvižkov, Epoka inteligencji. Historia poю wnawcza warstwy wykszta íconej w Europie, tłum. J. Górny, red. A. Kożuchowski, Warszawa 2011; tytuł oryginału: D. Sdvižkov, Das Zeitalter der Intelligenz: Zur vergleichenden Geschichte der Gebildeten in Europa bis zum Ersten Weltkrieg, Göttingen 2006.

2 D.A. Sdvižkov, Pis'ma s Prusskoj vojny. L di Rossijsko-imperatorskoj armii v 1758 godu, Moskva 2019.

3 Zob. M. Kupiec, Pole bitwy pod Sarbinowem (Zorndorf) jako obiekt turystyki kulturowej, „Turystyka Kulturowa” 2014, nr 9, s. 59-74.

4 T. Sebastian, Krajobraz po bitwie. Dwie relacje naocznychs wiadk $w$ dotycz ce rosyjskiego najazdu z 1758 r., [cz. 1], „Nadwarciański Rocznik Historyczno-Archiwalny” 2000, nr 7, t. 2, s. 229-242; K.F. Weber, Krajobraz po bitwie. Dwie relacje naocznychs wiadlo w dotycz ce rosyjskiego najazdu z 1758 r., [cz. 2], oprac. T. Sebastian, „Nadwarciański Rocznik Historyczno-Archiwalny” 2011, nr 8, s. 393-419; R. Skrycki, Angielska relacja o bitwie pod Sarbinowem i pierwszy drukowany plan bitwy, w: Chojna i okolice na przestrzeni wiek $w$, t. 2, Chojna 2008; najnowsza pozycja popularna: T. Rogacki, Zorndorf (Sarbinowo) 25 VIII 1758, Zabrze 2020.

5 J. Święcicki, Zorndorf - 25.08.1758, „Archeologia Wojskowa” 1993, nr 2, s. 39-42; G. Podruczny, J. Wrzosek, Odwo t przez Dworskie egi-jeden z epizod $w$ bitwy pod Sarbinowem stoczonej 25 sierpnia 1758 roku ws wietle przekax w historycznych $i$ badq archeologicznych, „Zeszyty Naukowe” 2011, nr 8: Nowa Marchia - prowincja zapomniana - Ziemia Lubuska wspo lne korzenie, s. 245-253; T. Karpiński, J. Wrzosek, Bitwa pod Sarbinowem (Zorndorf), pow. mys liborski, ws wietle badq archeologicznych, "Archeologia Środkowego Nadodrza” 2013, t. 10, s. 111-136; G. Podruczny, J. Wrzosek, Artillery Projectiles from the Battles of Zorndorf/Sarbinowo (1758) and Kunersdorf/Kunowice (1759), „Fasciculi Archaeologiae Historicae” 2012, fasc. 25, s. $77-85$.

${ }^{6}$ Zorndorf 1758: nierozstrzygnięta bitwa?, red. W.D. Brylla, B. Mykietów, M. Tureczek, Zielona Góra 2011. 
1758 roku. Rzecz w tym, że przez długi czas rosyjska strona była milcząca: świadectwa osobiste Prusaków, Francuzów, Austriaków i innych europejskich świadków znane były o wiele lepiej. Rosyjskie zasoby XVIII-wiecznych źródeł o charakterze osobistym, zwłaszcza korespondencji prywatnej, w ogóle są dość ubogie, a nieliczne wyjątki odnoszą się do archiwów kilku arystokratycznych rodów. Dlatego też, nie po raz pierwszy, unikalnego materiału dostarczają archiwa zagraniczne. Na przykład listy rosyjskich żołnierzy z 1700 roku „Z okopów” pod Narwą znalazły się w Narodowym Archiwum Szwecji ${ }^{7}$.

Recenzowanie książki D. Sdvižkova stanowi pewną trudność, wynikającą z jej nieco nietypowego charakteru. Podobnie jak inne wydania serii Archivalia Rossica wspólnego projektu wydawnictwa Nowoje Litieraturnoje Obozrienije i Niemieckiego Instytutu Historycznego w Moskwie - jest to przede wszystkim publikacja źródłowa. Publikacja, należy powiedzieć, solidnie przygotowana i doskonale nadająca się do naukowego wykorzystania. Obcojęzyczne teksty publikowane są $\mathrm{w}$ języku oryginału z tłumaczeniem na rosyjski (wyjątek zrobiono tylko dla kilku już wydanych materiałów). Są one opatrzone zwięzłymi genealogicznymi i prozopograficznymi komentarzami, a także odpowiednimi indeksami - osobowym oraz geograficznym. Sam zbiór źródeł poprzedza - i jest to chyba najważniejsza część pracy — obszerny komentarz, mający według zamierzeń autora „proponować, ale nie narzucać interpretację" (s. 16). Ów wstęp, jak to skromnie ujął autor - zajmujący około jednej trzeciej całej publikacji - stanowi de facto cenne i wnikliwe studium, oparte na bogatym zasobie źródeł archiwalnych ${ }^{8}$ i obszernej literaturze przedmiotu wydanej w kilku europejskich językach. Chociaż autor nie pretendował do napisania monografii, to jednak przyznał, że „w sposób naturalny wstępne komentarze rozrosły się w swego rodzaju histoire totale, czy w choć ograniczoną, ale encyklopedię wojennego oficerskiego życia danej epoki” (s. 17). Takie podejście sprawiło, że niezwykle bogaty i rozmaity materiał nie uzyskał wyraźnej, właściwej monografiom naukowym, struktury, co zresztą jest uzasadnione ze względu na jego kontekstualną, pomocniczą rolę. Kompozycja wstępu - zdecydowanie wolałbym pisać to słowo $\mathrm{w}$ cudzysłowie - choć podzielonego na rozdziały, pozostała więc dość umowna: niektóre wątki „wędrują” z jednego rozdziału do innego, a wiele cennych i ciekawych uwag znajduje się w komentarzach do poszczególnych dokumentów źródłowych.

Nie będzie zbędne następujące zastrzeżenie: optyka, którą przyjmuje badacz, wciąż jest nieco nietypowa dla wielu tradycyjnych, szczególnie popularnonau-

7 S.A. Kozlov, „Okopnye pis'ma russkih soldat 1700 g., w: Istori Rossii do XX veka. Novye podhody kizu eni . Kurs lekcij, Sankt-Peterburg 2008.

${ }^{8}$ Oprócz wspomnianego berlińskiego archiwum (GStA PK) autor pracował w Austriackim Archiwum Państwowym (OeStA) w Wiedniu, Rosyjskim Państwowym Archiwum Akt Dawnych (РГАДА) i Rosyjskim Państwowym Wojskowym Archiwum Historycznym (РГВИА) w Moskwie oraz w kilku innych. 
kowych, prac o historii wojskowości XVIII wieku. Po pierwsze, jego rozprawa jest znakomitą ilustracją tzw. nowej historii militarnej, nurtu w historiografii, który - jak pisał Peter Paret - „refers to a partial turning away from the great captains, and from weapons, tactics, and operations as the main concerns of the historical study of war. Instead we are asked to pay greater attention to the interaction of war with society, economics, politics, and culture". W centrum uwagi autora znajduje się więc nie przebieg działań wojennych, lecz ich uczestnicy. Opierając się na znalezionych przez siebie listach oraz licznych świadectwach epoki, D. Sdvižkov podejmuje szereg kwestii typowych dla „historii ludzi”, antropologii historycznej: życie codzienne oficerów, świat ich wartości i poglądów religijnych, stosunek do strachu, honoru, służby, własnego wojska i społeczności. Perspektywa antropologiczna pozwala mu spojrzeć na wojnę jak na „codzienność szczególnego rodzaju, której towarzyszą przeżycia ekstremalne" (s. 17). Takiemu spojrzeniu sprzyja specyfika źródeł: postrzeganie "gabinetowych” wojen w połowie XVIII wieku nie było jeszcze obciążone ideologicznymi i politycznymi konwencjami (s. 131), dlatego autorzy opisywali przede wszystkim „swoją”, „małą” wojnę - czy to koszmar przebywania pod ostrzałem armat, błądzenie po polu bitwy, czy to próbę ukrycia się przed atakiem pruskich husarów.

Po drugie, rozprawa stanowi dobry przykład badania mikrohistorycznego. Samo źródło podyktowało zawężenie perspektywy pod względem nie tylko chronologicznym i geograficznym, lecz także socjalnym - do pewnej grupy socjalno-zawodowej. Warto zauważyć, że w narracji D. Sdvižkova, jak i w klasycznych pracach tego nurtu, poszczególne przypadki i sytuacje ważne są nie same przez się, jako ciekawostki historyczne, lecz wpisują się w szeroki kontekst i stają się przyczynkiem do bardziej ogólnych rozważań o tym, czym była wojna w połowie XVIII stulecia. Zrozumiałe w ramach tego podejścia dążenie autora do zawężenia obszaru chronologicznego do jednego roku - 1758, i geograficznego - do niewielkiej przestrzeni w okolicach Kostrzyna, wpłynęło na dobór dodatkowych źródeł. W celu odtworzenia „maksymalnie autentycznego kontekstu” (s. 15) powstania listów autor włączył do publikacji fragmenty korespondencji zagranicznych ochotników w rosyjskiej armii, kilka przechwyconych przez Rosjan listów pruskich uczestników bitwy oraz wspomnienia dwóch lokalnych świadków o wydarzeniach z 1758 roku, opublikowane anonimowo bezpośrednio po zakończeniu kampanii.

Metodologiczne priorytety D. Sdvižkova wyraźnie wybrzmiewają w części pracy poświęconej szczegółowej rekonstrukcji całej kampanii (s. 41-127) — od wojennych planów do losów jeńców. Chociaż autor przedstawia całokształt faktów niezbędnych dla zrozumienia przebiegu działań wojennych, w centrum jego uwagi zawsze znajduje się osobiste, bezpośrednie przeżywanie bitwy przez jej

\footnotetext{
9 P. Paret, e New Military History, „Parameters” 1991, vol. 21, no. 1, s. 10.
} 
uczestników ${ }^{10}$, do czego przyczynia się obfite cytowanie i zestawienie rosyjskich i pruskich „świadectw osobistych”. W tekście znalazło się miejsce dla wątków, które raczej rzadko występowały w tradycyjnej „batalistyce”, na przykład dla rozważań o strategii przetrwania podczas schwytania do niewoli, o symbolicznym znaczeniu czasu i zegarków, stosunku do pozostałych na polu boju ciał poległych albo o pierwszorzędności dźwiękowych wrażeń z bitwy dla jej świadków w „cichym” XVIII wieku. Bitwa w takiej narracji ukazuje się jako szereg oddzielnych, często chaotycznych scen obserwowanych z bliska. Autor podkreśla fakt, niekiedy umykający uwadze przy postrzeganiu wczesnonowożytnych batalii: jak mało zależało w rzeczywistości od naczelnego dowództwa i jak wiele kluczowych decyzji podejmowanych było spontanicznie, przez poszczególnych oficerów. Nie tylko rosyjski generał en chef Wilhelm Fermor po ustawieniu swego wojska w ordre de bataille praktycznie nie próbował kontrolować jego działań, lecz także król pruski musiał się uporać z ogromnymi problemami w dowodzeniu własną armią w miejscu, które bardzo szybko spowiły nieprzeniknione kłęby kurzu i dymu. Pod wieczór, kiedy obie strony całkowicie wyczerpały swe siły, bitwa przekształciła się w ciąg drobnych potyczek między rozproszonymi grupami żołnierzy. W takich warunkach Fryderyk II nie był w stanie zgromadzić swoich zmęczonych, przestraszonych czy zajętych grabieżami ludzi do rozstrzygającego ataku. Z jednej strony, biorąc pod uwagę kolosalne straty wśród oficerów, to przedsiębiorczość poszczególnych dowódców i zdolność żołnierzy do samoorganizacji uratowały rosyjską armię przed całkowitą klęską. Z drugiej strony, jak zauważa autor, epizody z utratą kontroli, naruszeniem subordynacji i masowym pijaństwem - rosyjscy żołnierze z rozbitych oddziałów splądrowali własny tabor i się upili - wyraźnie wskazywały na to, że zdolności armii cesarzowej Elżbiety do prowadzenia regularnej wojny pozostawiały wiele do życzenia (s. 99).

W następnych częściach pracy autor podejmuje wątki związane z życiem codziennym oficerów, w tym z ich kłopotami finansowymi, przyjaźniami i relacjami rodzinnymi, ideałami i wartościami. Ale już wcześniej, zajmując się charakterystyką źródła (s. 25-41), badacz w istocie porusza temat postępów i granic „westernizacji" ówczesnych rosyjskich wojskowych i, szerzej, szlachty. Przed wojną tylko $70 \%$ oficerów piechoty rosyjskiej umiało czytać i pisać, przy czym w czasie działań wojennych odsetek ten ze zrozumiałych powodów się zmniejszał. Badacz podkreśla, że $\mathrm{w}$ opisywanym czasie wciąż mamy do czynienia $\mathrm{z}$ okresem przejściowym: $\mathrm{w}$ wojsku służą oficerowie $\mathrm{z}$ różnych pokoleń i grup społecznych. Styl i tematyka niektórych listów, nawet tych pióra ober- i sztabsoficerów, niewiele się różnią od takowych w tzw. gramotkach XVII i początku XVIII wieku. Etykieta epistolarna w latach 50. XVIII wieku jest bliższa początkowi stulecia niż jego końcowi, a charakter pisma, słowne formuły, archaizm wspominanych imion

${ }^{10}$ Zob. przykład podobnej narracji: P. Englund, Po łtawa, tłum. W. Łygaś, Gdańsk 2015. 
mogą niekiedy przywodzić na myśl jeszcze czasy przedpiotrowe. Niemniej jednak oczywiste jest, że dokonały się głębokie zmiany i ludzie młodzi wybierali już styl w zależności od adresata: archaiczny w korespondencji z rodzicami, a bardziej współczesny, lekki i elegancki w listach do przyjaciół i ukochanych. Chociaż wśród znanych rosyjskim oficerom języków obcych wciąż dominował niemiecki, autor zwraca także uwagę na oznaki postępującej galomanii, listy niektórych przedstawicieli stołecznej młodzieży $\mathrm{z}$ analizowanego zbioru były już pisane po francusku.

Ogólnie rzecz biorąc, pod koniec panowania Elżbiety Piotrowny rosyjskiej wspólnocie oficerskiej jeszcze dużo brakowało do blasku, jaki czasem przypisywało się jej - raczej stereotypowo - w epoce Katarzyny II i Aleksandra I. Nic więc dziwnego, że z punktu widzenia zachodnich Europejczyków gusty jej przedstawicieli wydają się bardzo prowincjonalne. Pewien austriacki obserwator prosił o przesłanie mu z Wiednia groszowej i jaskrawej galanterii: tabakierek, papierośnic, łańcuszków do zegarka etc. - towarów bardzo cenionych przez rosyjskich oficerów i pozwalających zdobyć „wiele przyjaciół i duży szacunek” (s. 153). Sytuacja materialna wielu młodszych oficerów w warunkach wojny była bardzo ciężka, co czyniło ich całkowicie zależnymi od wsparcia rodziny. Tym między innymi, jak uważa autor, można wyjaśnić ekscesy z miejscową ludnością: w odróżnieniu od innych europejskich państw, w rosyjskiej armii nie praktykowano podnoszenia bardzo skromnego żołdu oficerów uczestniczących w zagranicznych wyprawach, co czyniło ich samodzielne przetrwanie za zachodnią granicą zadaniem prawie niemożliwym (s. 139-140). Przez rodziny zamożniejszych oficerów wojna mogła być postrzegana jako okazja do wzrostu ich dobrobytu. Oficerowie czasem otrzymywali z domu odpowiednie „zamówienia” - chodziło zresztą nie tyle o zdobycz, ile o pamiątki czy po prostu udane zakupy w bogatszych ziemiach, na przykład paradnych obrusów (s. 152-153).

Interesujące, że szlachecki etos wówczas jeszcze się kształtował. Niektórzy oficerowie całkiem szczerze przyznawali się do słabości, strachu czy wręcz tchórzostwa. Temat ten nie do końca bowiem był jeszcze objęty tabu, w odróżnieniu na przykład od późniejszej epoki napoleońskiej. W listach wojskowi, którzy dopiero co przeżyli ogromny stres, usilnie prosili krewnych i znajomych, aby ci „postarali się” dla nich o urlop, ponieważ „już nie mogą” („мочи нет”). Powołanie do armii polowej postrzegane było jako dotkliwy cios - tak przez samych oficerów, jak i przez ich bliskich. Autor konstatuje, że badany przez niego zbiór listów praktycznie nie zawiera śladów wojennego entuzjazmu. Rosyjska armia nie była więc pewna swej siły, a perspektywa powtórnego zmierzenia się z groźnym nieprzyjacielem, mimo odniesionego „zwycięstwa”, wywoływała niemały strach. Zrozumiała jest zatem popularność, jaką wśród bardzo wielu ludzi — od zwyczajnych oficerów, autorów listów, do cesarzowej Elżbiety - zyskał pogląd, że największe znaczenie bitwy po- 
legało na tym, że rosyjska armia wytrzymała zderzenie z samym niezwyciężonym Fryderykiem II (s. 124-126).

Bynajmniej niejednoznaczny był także stosunek do służby jako takiej. D. Sdvižkov wymienia ideał pokoju, czy raczej spokoju (покой) - ucieleśnionego w życiu rodzinnym i domowym - jako jedną z najważniejszych kategorii w świadomości ówczesnej szlachty rosyjskiej. Stała i czynna służba państwu, będąca podstawowym wymaganiem Piotra I wobec dworiaństwa, stanowiła zaprzeczenie pokoju i powszechnie była odbierana jako uciążliwy obowiązek. Nawet w połowie XVIII wieku prowokowało to komentarze cudzoziemców o tym, że „Rosjanie z natury nienawidzą służby” (s. 195). Jednak właśnie w czasach wojny siedmioletniej autor dostrzega początek poważnych zmian: służbę zaczęto postrzegać jako przywilej, zaszczytny obowiązek, jako naturalne zajęcie szlachcica. Służba wojskowa stała się świadomym i dobrowolnym wyborem, który umożliwia połączenie nowych patriotycznych wartości służenia Ojczyźnie z korzystnymi strategiami kariery - szczególnie w czasie wojny. Oczekiwanie szybkich awansów, jakie nastąpią po śmierci wielu towarzyszy broni, oraz gratulacje składane żonom z okazji nadania nowego stopnia (w tradycji rosyjskiej stopień wojskowy oficera w pełni odnosił się również do jego małżonki) należą do częstych wątków w opublikowanej przez D. Sdvižkova korespondencji uczestników bitwy pod Sarbinowem.

Ciekawe są rozważania autora na temat religijności w ówczesnej armii Cesarstwa Rosyjskiego (s. 180-193). Pomimo wyraźnie sekularystycznych tendencji z początku stulecia atmosfera rządów nabożnej Elżbiety Piotrowny przyczyniła się do pewnego odrodzenia staromoskiewskiej pobożności. Reformy Piotra I stworzyły pobożność nowego typu, która dopuszczała istnienie dwóch rzeczywistości - duchowej i świeckiej. Każda z nich, w zależności od sytuacji, wyznaczała różne strategie życiowe. Okres wojny, służby wojskowej, teoretycznie należał do świeckiego, państwowego czasu. Religijny punkt widzenia - według którego przetrwanie na wojnie zależy przede wszystkim od wysiłków duchowych, a rany i śmierć mogą być konsekwencją grzechów osobistych - wyraźnie jednak dominował wśród oficerów i żołnierzy. Przykładowo, więcej niż dwie trzecie rosyjskiej armii ekspedycyjnej przestrzegało postu, bez względu na specjalne rządowe zezwolenie czy wręcz zalecenie porzucenia tej praktyki na czas kampanii. Z kolei korzystanie z sakramentów spowiedzi i Eucharystii, co było typowe dla ówczesnej rosyjskiej religijności, było dość rzadkie. Z punktu widzenia wojskowych tradycjonalistów nieprzestrzeganie postu mogło być odbierane jako przejaw obcych, niemieckich wpływów. Wstawiennictwo sił wyższych miało ocalić od ran i śmierci, dlatego zarówno żołnierze, jak i oficerowie wszywali w ubranie ikonki, psalmy i amulety, a niektórzy podczas bitwy nosili na sobie całe ikony. Wynik batalii, co zresztą było właściwe także dla innych europejskich społeczeństw, rozumiano jako rezultat modlitewnych 
starań - nie tylko bezpośrednich uczestników walk, lecz i pośredników, „bogomolców”, przede wszystkim zaś duchowieństwa. Na poziomie indywidualnym rolę pośredników wspierających walczących modlitwą przyjmowali ci, którzy zostali w domu - rodzice, żony, siostry żołnierzy. D. Sdvižkov w związku z tym szczególnie eksponuje dużą popularność, jaką zdobył wśród rodzin ówczesnej szlachty kult św. Dymitra z Rostowa, pierwszego świętego tzw. okresu synodalnego, kanonizowanego w 1757 roku, równocześnie z przystąpieniem Rosji do wojny siedmioletniej.

Specyfika źródeł ukierunkowała uwagę autora również na kwestię współistnienia w korpusie oficerskim różnych grup narodowościowych (s. 160—164, 402-405). Około jednej piątej wszystkich listów w prezentowanym przez niego korpusie źródeł stanowią listy w języku niemieckim, napisane głównie przez oficerów pochodzenia „bałtyckiego”. D. Sdvižkov zwraca uwagę na wciąż autonomiczną w tym czasie samoświadomość „Ostzejców” w składzie Cesarstwa. Z jednej strony dość wyraźnie identyfikowali oni siebie jako „niemieckich” oficerów i luteranów. Z drugiej strony źródła świadczą o coraz szerszych ich kontaktach z językiem i kulturą rosyjską. Do tekstów stopniowo przenikały rusycyzmy, a niekiedy nawet całe rosyjskie konstrukcje gramatyczne. Zwycięstwo pod Sarbinowem - a wszyscy autorzy listów są przekonani, że to Rosja je odniosła - traktowali jako własne, „nasze” zwycięstwo. Analizując materiał źródłowy, autor zauważa jednak, że Niemcy utożsamiali siebie z rosyjsko-cesarsk armią, nie zaś, co znamienne, z rosyjską (warto tutaj przypomnieć o wiele późniejsze, ale trafne powiedzenie cara Mikołaja I o tym, że „szlachta rosyjska służy państwu, a niemiecka - nam”). Opowiadając o stratach swoich pułków w listach do rodziny, wspominali tylko „swoich” poległych, tj. oficerów Niemców. Bynajmniej nie wszyscy z nich zginęli z rąk Prusaków. Podczas zgiełku wojennego i ogólnego zamieszania wielu niemieckich oficerów zostało zamordowanych przez własnych żołnierzy. Nieufność wobec Niemców była rozpowszechniona także wśród rosyjskich oficerów, postrzegano ich jako potencjalnych wewnętrznych wrogów i zdrajców. Brak zaufania w armii do głównodowodzącego Wilhelma Fermora stał się prawdopodobnie jedną z przyczyn mianowania w 1759 roku na to stanowisko Rosjanina - Piotra Sałtykowa.

Autor kilkakrotnie porusza w rozprawie temat znaczącej roli Rzeczypospolitej w kampanii 1758 roku. Rzeczywiście, jak zauważał Tomasz Ciesielski, nawet jeśli Rzeczpospolita była, według słów Władysława Konopczyńskiego, „zajezdną karczmą" Europy, to Rosjanie mogli liczyć w niej na znacznie lepszą „obsługę"11. I chodziło nie tylko o życzliwą neutralność i dostarczanie żywności, bez czego, jak podkreśla D. Sdvižkov, działania wojenne Rosjan poza granicami Prus Wschodnich byłyby niemożliwe. Jak wynika z jego badań, to właśnie Polacy, przede wszystkim

${ }_{11}$ T. Ciesielski, Pogranicze polsko-pruskie w dobie wojny siedmioletniej, „Komunikaty Mazursko-Warmińskie" 2008, nr 1, s. 7. 
duchowni katoliccy, tworzyli sieć rosyjskich konfidentów na terenach przygranicznych, a na czele tej obszernej struktury, sięgającej Berlina, stał niejaki Józef Lok (Иосиф Лок), opat klasztoru przy granicy z Pomorzem - szczodrze wynagradzany za swoje usługi złotem i futrami (s. 52). Rolę lojalnych wobec Rosji polskich magnatów po części ilustrują opublikowane w książce fragmenty korespondencji młodego Antoniego Sułkowskiego, polskiego ochotnika w rosyjskiej armii, z jego ojcem - księciem Aleksandrem Józefem Sułkowskim, kawalerem kilku rosyjskich orderów oraz jednym z głównych dostawców żywności dla Rosjan (s. 476-484). Prawdziwym polskim karczmarzom w północno-zachodnich województwach rosyjscy wojskowi zresztą również stworzyli okazję do zarobku. Podczas gdy dostęp do armii był otwarty dla Niemców i Polaków, to Żydów należało trzymać od obozów z dala, w związku z czym autor przypomina o antyżydowskiej polityce Elżbiety Piotrowny (s. 145).

Autor kończy swój wstępny wywód rozważaniami nad wpływem wojny siedmioletniej na przyszłe wydarzenia oraz jej miejscem w pamięci historycznej (s. 198-206). O ile w Prusach wojna, w tym bitwa pod Sarbinowem, stała się jedną z najważniejszych części legendy Fryderyka II, o tyle w rosyjskich oficjalnych narracjach ten dziwny i bezowocny konflikt zają bardzo skromne miejsce. Paradoksalnie, lepiej pamięć o bitwie i całej wojnie siedmioletniej przetrwała w poszczególnych szlacheckich rodzinach i ludowym folklorze rosyjskim. Niemniej w ogólnej ocenie D. Sdvižkova wojna wywarła pozytywny wpływ na doświadczenie kadry oficerskiej i utorowała drogę do reform wojskowych, które w przyszłości umożliwiły Katarzynie II rozwiązywanie ambitnych zadań geopolitycznych. Jednocześnie, jak zaznacza D. Sdvižkov, Zorndorf przyczynił się do utrwalenia raczej szkodliwego autostereotypu o „nieugiętej niezłomności” rosyjskich wojsk, mogącej rzekomo zniwelować brak dyscypliny i wady organizacji. Przekonanie to w przyszłych wojnach kosztowało rosyjską armię wiele istnień ludzkich. Także dla zjednoczonych Niemiec sława bitew wojny siedmioletniej i jej spuścizna militarno-teoretyczna obróciły się w katastrofy wieku XX, kiedy to żaden „cud domu brandenburskiego" nie uratował państwa przed nieuniknioną klęską w walce na kilka frontów.

Doświadczenie wojny siedmioletniej pokazało rosyjskiemu rządowi, że Prusy są "kluczowym graczem w tym regionie”, a "pasywna rola Polski podpowiadała stawki w tej grze” (s. 202). Można by dodać, że nie chodziło tylko o polską „,bierność" - zjawisko zresztą zauważalne w europejskiej polityce od dłuższego czasu. W trakcie wojny Petersburg miał okazję się przekonać, jak ogromne znaczenie ma teren i zasoby Rzeczypospolitej dla wszelkich działań rosyjskiej armii w zachodnim kierunku, i równocześnie dostrzec, jak chwiejne i niewystarczające są jego wpływy w warunkach powstałego po 1717 roku status quo w relacjach rosyjsko-polskich. Nic dziwnego, że właśnie w wyniku wojny siedmioletniej, kiedy to osłabiły się 
wpływy Francji i monarchii Habsburgów, w Petersburgu wyciągnięto odpowiednie wnioski i postanowiono sięgnąć po bardziej radykalne środki, aby zapewnić rosyjską dominację na tym obszarze ${ }^{12}$.

Ryzykując pominięciem wielu niuansów i bynajmniej nie wyczerpując całego bogactwa poruszonych w omawianej pracy wątków, starałem się pokrótce przedstawić najważniejsze podjęte w niej kwestie. Niezależna, niemal demonstracyjnie, od wszelkiego rodzaju patriotycznych wielkich narracji - traktowanych z dużą ironią, jak choćby mity „fridericiany” - erudycyjna książka Denisa Sdvižkova stanowi barwną ilustrację współczesnej historiografii. Rozumiem przez to m.in. dużą wagę, jaką autor przywiązuje do stylu narracji - trudno nie zauważyć, że rezygnacja ze ścisłych czy wręcz skostniałych naukowych form pozwoliła mu stworzyć udaną i oryginalną pracę również pod względem literackim. Na przykład nawiązując do barokowej metaforyki theatrum belli (s. 133-134), historyk nadał swojemu opisowi kampanii 1758 roku strukturę opery - składającej się z preludium, kilku aktów, intermezzo i coro f.nale. Napisana przez doświadczonego badacza książka łączy w sobie to, czego zazwyczaj oczekuje się od naprawdę dobrej i profesjonalnej pracy historycznej: wyróżnia się umiejętnym i szerokim zastosowaniem materiałów archiwalnych oraz aktualnymi rozwiązaniami metodologicznymi. Wartość poznawcza książki znacznie wykracza zresztą poza samo zagadnienie wojny siedmioletniej. Przede wszystkim dzięki przyjętym podstawom metodologicznym jest to udany przykład antropologicznego i mikrohistorycznego podejścia umożliwiającego maksymalne wykorzystanie potencjału źródeł o pochodzeniu osobistym. Wątpię, żeby jakakolwiek poważna rozprawa poświęcona rekonstrukcji bitwy pod Sarbinowem albo udziałowi Rosji w wojnie siedmioletniej mogła się teraz obejść bez cytowania lub powoływania się na tę publikację. Recenzowana książka stanowi również ważny przyczynek do wiedzy o armii, której obecność na ziemiach Rzeczypospolitej stała się od tamtej pory prawie nieprzerwana.

Bibliografia

Ciesielski T., Pogranicze polsko-pruskie $w$ dobie wojny siedmioletniej, „Komunikaty Mazursko-Warmińskie" 2008, nr 1, s. 3-17.

Englund P., Po itawa, tłum. W. Łygaś, Gdańsk 2015.

Karpiński T., Wrzosek J., Bitwa pod Sarbinowem (Zorndorf), pow. mys liborski, ws wietle badøa archeologicznych, „Archeologia Środkowego Nadodrza” 2013, t. 10, s. 111-136.

Kozlov S.A., „Okopnye pis'ma russkih soldat 1700 g., w: Istori Rossii do XX veka. Novye podhody kizu eni . Kurs lekcij, Sankt-Peterburg 2008.

12 B.V. Nosov, Ustanovlenie rossijskogo gospodstva v Re i Pospolitoj. 1756-1768 gg., Moskva 2004, s. 33-34, 62-64. 
Kupiec M., Pole bitwy pod Sarbinowem (Zorndorf) jako obiekt turystyki kulturowej, „Turystyka Kulturowa" 2014, nr 9, s. 59-74.

Nosov B.V., Ustanovlenie rossijskogo gospodstva v Re i Pospolitoj. 1756-1768 gg., Moskva 2004.

Paret P., e New Military History, „Parameters” 1991, vol. 21, no. 1, s. 10-18.

Podruczny G., Wrzosek J., Artillery Projectiles from the Battles of Zorndorf/Sarbinowo (1758) and Kunersdorf/Kunowice (1759), „Fasciculi Archaeologiae Historicae” 2012, fasc. 25, s. 77-85.

Podruczny G., Wrzosek J., Odwo t przez Dworskie egi-jeden z epizod w bitwy pod Sarbinowem stoczonej 25 sierpnia 1758 roku ws wietle przekas w historycznych i badø archeologicznych, „Zeszyty Naukowe" 2011, nr 8: Nowa Marchia - prowincja zapomniana - Ziemia Lubuska - wsp lne korzenie, s. 245-253.

Rogacki T., Zorndorf (Sarbinowo) 25 VIII 1758, Zabrze 2020.

Sdvižkov D., Das Zeitalter der Intelligenz: Zur vergleichenden Geschichte der Gebildeten in Europa bis zum Ersten Weltkrieg, Göttingen 2006.

Sdvižkov D., Epoka inteligencji. Historia pon wnawcza warstwy wykszta íconej w Europie, tłum. J. Górny, red. A. Kożuchowski, Warszawa 2011.

Sdvižkov D.A., Pis’ma s Prusskoj vojny. L di Rossijsko-imperatorskoj armii v 1758 godu, Moskva 2019.

Sebastian T., Krajobraz po bitwie. Dwie relacje naocznych s wiadk $w$ dotycz ce rosyjskiego najazdu z 1758 r., [cz. 1], „Nadwarciański Rocznik Historyczno-Archiwalny” 2000, nr 7, t. 2, s. $229-242$.

Skrycki R., Angielska relacja o bitwie pod Sarbinowem i pierwszy drukowany plan bitwy, w: Chojna i okolice na przestrzeni wielo $w$, t. 2. Chojna 2008.

Święcicki J., Zorndorf - 25.08.1758, „Archeologia Wojskowa” 1993, nr 2, s. 39-42.

Weber K.F., Krajobraz po bitwie. Dwie relacje naocznychs wiadlo $w$ dotycz ce rosyjskiego najazdu $z 1758$ r., [cz. 2], oprac. T. Sebastian, „Nadwarciański Rocznik Historyczno-Archiwalny” 2011, nr 8, s. 393-419.

Zorndorf 1758: nierozstrzygnięta bitwa?, red. W.D. Brylla, B. Mykietów, M. Tureczek, Zielona Góra 2011.

Dymitr Grygiencza

The Battle of Zorndorf/Sarbinowo (1758)

in the Light of Letters from Russian Officers:

a New Publication about the Russian Army during the Seven Years' War

[Rev. Denis Anatolevič Sdvižkov, Pis’ma s Prusskoj vojny. L di Rossijsko-imperatorskoj

armii v 1758 godu, Moskva 2019]

Summary

Denis Sdvižkov's book Letters from the Prussian War combines the source material - consisting of a collection of private and official correspondence of officers of the Imperial Russian Army, direct participants in and witnesses of the Seven Years' War (1756-1763) - with an extensive and original introductory study. Using anthropological and microhistorical approaches in an analysis of numerous personal testimonies, the Author shows how the daily life during the war and the key event of the 1758 campaign - the Battle of Zorndorf/Sarbinowo - were reflected in the experience 
of the Russian military. In addition to reconstructing the battle itself, the book pays much attention to everyday life, career strategies, values, religiosity and morality of the members of the Russian officer corps as well as to the role of the Zorndorf battle in the war propaganda and the historical memory in Russia and Prussia.

Key words: the Seven Year's War, the Battle of Sarbinowo/Zorndorf, Russian Army, military history 